\title{
Shellfish tissues evaluated for Perkinsus spp. using the Ray's fluid thioglycollate medium culture assay can be used for downstream molecular assays
}

\author{
C. Audemard*, R. B. Carnegie, E. M. Burreson \\ Virginia Institute of Marine Science, College of William and Mary, Route 1208, Greate Road, Gloucester Point, \\ Virginia 23062, USA
}

\begin{abstract}
Ray's fluid thioglycollate medium (RFTM) culture assay is the standard, recommended method for surveillance of Perkinsus spp. infections in marine molluscs. In this assay, shellfish tissues are incubated in RFTM, stained with Lugol's iodine solution to render Perkinsus spp. cells blue-black, and evaluated microscopically to rate infection intensities. A limitation of this assay, however, is the lack of pathogen species specificity. Generally, identification of Perkinsus spp. requires DNA sequence analysis of parallel or additional samples since the exposure to iodine is believed to hamper DNA amplification from samples processed by the RFTM assay. However, we show that $P$. marinus DNA can be successfully amplified by PCR from Crassostrea virginica tissues cultured in RFTM and stained with Lugol's iodine. The beneficial consequence is that, where necessary, DNA sequence data may be obtained from RFTM-cultured tissues, allowing the identification of the Perkinsus sp. responsible for an observed infection. This would obviate further sampling, representing gain of time and reduction in cost, where a Perkinsus sp. is unexpectedly observed in new host(s) or location(s) but where parallel samples are not available for molecular diagnostics. Laboratories without molecular diagnostic tools for Perkinsus spp. may fix presumptive Perkinsus sp.-positive culture material in $95 \%$ ethanol for transport to, and subsequent analysis by, a laboratory that does have this capacity.
\end{abstract}

KEY WORDS: Perkinsus $\cdot$ Dermo disease $\cdot$ RFTM $\cdot$ Lugol's iodine $\cdot$ DNA $\cdot$ PCR

Resale or republication not permitted without written consent of the publishe

\section{INTRODUCTION}

Protistan parasites in the genus Perkinsus infect diverse marine molluscs worldwide including oysters, clams, scallops, and abalone. Currently, 7 Perkinsus species are recognized: $P$. marinus, infecting the oyster Crassostrea virginica along the Atlantic and Gulf of Mexico Coasts of the USA (Mackin et al. 1950); P. olseni, described from the abalone Haliotis rubra in Australia but currently known to infect hosts from Asia, New Zealand, South America, and Europe (Lester \& Davis 1981, Elston et al. 2003, Villalba et al. 2004); P. ugwadi, in the scallop Patinopecten yessoensis in British
Columbia, Canada (Blackbourn et al. 1998); P. chesapeaki, infecting an array of clams (and $C$. virginica) in the mid-Atlantic region of the USA (Burreson et al. 2005); P. mediterraneus, from the oyster Ostrea edulis in the Balearic Islands (Spain) of the Mediterranean Sea (Casas et al. 2004); P. honshuensis, from Japanese Manila clams (Dungan \& Reece 2006); and P. beihaiensis, from Chinese Crassostrea spp. oysters (Moss et al. 2008). Among these species, P. marinus and P. olseni are economically significant pathogens listed as 'notifiable' by the World Organisation for Animal Health (OIE).

The standard diagnostic method recommended for surveillance of Perkinsus spp. infections is Ray's fluid 
thioglycollate medium (RFTM) culture assay. This assay was developed in the early 1950s (Ray 1952, 1966), after P. marinus was described in Crassostrea virginica in the Gulf of Mexico (Mackin et al. 1950). In this assay, pieces of animal tissue, usually mantle and/or rectum, are incubated in RFTM for several days during which Perkinsus spp. cells enlarge from 2-10 $\mu \mathrm{m}$ to $50-70 \mu \mathrm{m}$, forming hypnospores. After incubation, the enlarged cell walls are stained blueblack by the addition of Lugol's iodine, and stained Perkinsus spp. cells can be easily observed under a microscope. This assay presents advantages of low cost and simplicity relative to histology, and the infection intensity data collected are semi-quantitative. Furthermore, this diagnostic assay is more sensitive than histological methods (McLaughlin \& Faisal 1999). One of the major limitations of the RFTM assay, however, is that it does not allow discrimination among Perkinsus spp. In fact, even Perkinsus spp. observed histologically cannot be identified to species based on morphological characteristics alone. Rather, identification of Perkinsus spp. requires the analysis of DNA sequences, in particular, ribosomal DNA nontranscribed spacer (NTS) and/or internal transcribed spacer (ITS) sequences (Goggin 1994, Marsh et al. 1995, Robledo et al. 1998, Casas et al. 2004, Burreson et al. 2005).

Samples for molecular analysis and DNA-based species identifications by laboratories that have such capabilities are generally preserved from recently shucked animals, while separate tissue samples are used for RFTM assay determination of infection prevalence and intensity; additional tissue samples may be fixed and processed for histology. It is often the case with microparasites like Perkinsus spp., however, that the few parasite cells present in a very light infection may be captured in one tissue sample, but not in others. Such animals may be, among other possible outcomes, RFTM-positive for a Perkinsus sp. but histology- and PCR-negative. In such cases, the identity of a Perkinsus sp. observed by RFTM cannot definitively be resolved. It is also the case that many laboratories are not equipped for molecular diagnostics, and therefore use only RFTM assays, the OIErecommended gold-standard tool, and histology for surveillance of Perkinsus spp. infections. While this may reasonably suffice for routine detection of a Perkinsus sp. in a known host from a locality in which a particular Perkinsus sp. is known to be enzootic, this is not adequate for establishing new host records, or for drawing conclusions about a parasite's possible geographic range expansion. In examples such as these, it is unfortunate that definitive parasite species identifications cannot be established from RFTMassayed tissue samples.
To our knowledge, there have been no attempts to PCR-amplify Perkinsus sp. DNA from RFTM-cultured, Lugol's iodine-stained material. This may be due to the common belief that the exposure to iodine may compromise downstream PCR amplification (Godhe et al. 2002). This has never been tested, however, in the case of RFTM-iodine processed tissues. If such amplifications were possible, identification of a Perkinsus sp. parasite to species would be possible even if parallel samples were not preserved specifically for molecular work, and without the time and expense of resampling a host population. In the reported study, our objective was to determine whether $P$. marinus in tissues processed for RFTM assays and stained with Lugol's iodine would be PCR-amplifiable following microscopic observation.

\section{MATERIALS AND METHODS}

Samples analyzed. The oyster samples were Crassostrea virginica $(\mathrm{n}=67)$ collected during the fall of 2007 from 2 sites located in the Perkinsus marinusenzootic Virginia portion of the Chesapeake Bay (USA), Tangier Sound $(\mathrm{n}=45)$ and Pocomoke Sound ( $\mathrm{n}=22)$.

RFTM assays. Upon arrival at the laboratory, oysters were processed for RFTM assays as follows. After oysters had been cleaned and measured, they were shucked, with pieces (5 to $10 \mathrm{~mm}^{2}$ ) of gill, mantle and rectum excised and immersed in RFTM. Antimycotics and antibiotics comprising 200 units of mycostatin (Nystatin), 500 units penicillin G, and $500 \mathrm{mg}$ dihydrostreptomycin per $\mathrm{ml}$ of media were added before placing the tubes into an incubator at 22 to $25^{\circ} \mathrm{C}$. After 5 to $7 \mathrm{~d}$, tissues were removed from the RFTM and placed on a glass slide. Then, 1 to 2 drops of $20 \%$ (v/v) Lugol's iodine solution were added, and tissues were macerated using a scalpel blade before being coverslipped. Scalpel blades were immersed in $95 \% \mathrm{EtOH}$ and then flamed between each sample to prevent cross-contamination. The preparation was examined under a microscope, and Perkinsus sp. infection intensities were ranked based on the scale of Mackin (Ray 1954): no detection; rare (1 to 2 parasites found in entire preparation); very light (3 to 10 parasites found in entire tissue preparation); light (11 to 100 cells in entire preparation); light-moderate (some areas free of parasites but other areas showing localized concentrations of 24 to 50 cells, or cells uniformly distributed such that 2 to 3 cells occur in each $100 \times$ field); moderate (parasites so numerous that $>3$ cells are present in all fields at $100 \times$, but masses of $>50$ cells are still more or less localized, tissue not showing blue/black color macroscopically); moderate-heavy (parasite cells present in large num- 
bers in all tissues, but less than half of the tissue showing a blue/black color macroscopically); or heavy (parasite cells in enormous numbers, with the major part of tissue appearing blue/black macroscopically).

DNA extraction. Once the preparations had been examined under a microscope and Perkinsus sp. infections had been rated, the coverslip from each sample was removed using a scalpel, and tissues were scraped into a tube containing 10 volumes of $95 \%$ ethanol per 1 volume of tissue. As described earlier, scalpel blades were flamed between samples to minimize the risks of contamination from sample to sample. DNA was extracted from ethanol-preserved tissue using a DNeasy Tissue Kit (Qiagen). The volumes of lysis buffer and Proteinase $\mathrm{K}$ added were adjusted to the volume of oyster tissues preserved so all the tissue collected from each RFTM slide could be lysed. In general, the volume of lysis buffer provided by the kit was $720 \mu \mathrm{l}$ and the volume of Proteinase K was $80 \mu \mathrm{l}$. After lysis, a subsample of $400 \mu \mathrm{l}$ of the lysate was processed for DNA extraction following the manufacturer's protocol. DNA was quantified with a GeneQuant Pro spectrophotometer (Amersham Biosciences).

PCR assays. PCR was performed on each of the extracted DNA samples using Perkinsus genus ITS-1 rDNA-specific primers PerkITS (Audemard et al. 2004), P. marinus ITS-1 rDNA-specific primers PmarITS (Audemard et al. 2004), and P. chesapeaki ITS-1 rDNA-specific primers PchesITS (Burreson et al. 2005). The sizes of the amplified PCR fragments were 703, 509, and 670 base pairs, respectively. Reaction and amplification conditions were as previously described (Audemard et al. 2004, Burreson et al. 2005). The volume of DNA per reaction ranged from 0.5 to $2.0 \mu \mathrm{l}$ depending on the DNA concentration of the sample, such that the amount of DNA template per PCR reaction was $200 \mathrm{ng}$. Each PCR experiment included a known Perkinsus sp.-positive sample as a positive control, and a no-template sample (DNA replaced with water) as a negative control. Amplification products were electrophoresed in $2 \%$ agarose gels (in $1 \times$ TrisAcetate EDTA buffer), stained with ethidium bromide, and visualized under UV light.

\section{RESULTS}

\section{RFTM assay results}

Among the oysters analyzed, infection intensities based on RFTM assay results ranged from rare to heavy, with most of the infected oysters (37/67) characterized by light-moderate infections. Perkinsus sp. was not detected by RFTM assays in 9 individuals (Table 1).
Table 1. Results from RFTM assays (number of oysters according to categories of infection intensity) and subsequent PCR assays on the same individuals with the number (percentage) of PCR positive per infection category. Perkinsus chesapeaki was not detected in any sample

\begin{tabular}{|lccc|}
\hline $\begin{array}{l}\text { RFTM infection } \\
\text { intensity }\end{array}$ & $\begin{array}{c}\text { No. of } \\
\text { oysters }\end{array}$ & \multicolumn{2}{c|}{$\begin{array}{c}\text { No. of PCR positive (\%) } \\
\text { Perkinsus spp. }\end{array}$} \\
\hline Negative marinus \\
Rare & 9 & $9(100)$ & $8(88)$ \\
Very light & 5 & $5(100)$ & $3(60)$ \\
Light & 6 & $6(100)$ & $6(100)$ \\
Light-moderate & 12 & $12(100)$ & $11(92)$ \\
Moderate & 25 & $25(100)$ & $25(100)$ \\
Moderate-heavy & 2 & $7(100)$ & $7(100)$ \\
Heavy & 1 & $2(100)$ & $2(100)$ \\
& & $1(100)$ & $1(100)$ \\
\hline
\end{tabular}

\section{DNA concentrations}

DNA extracted from the all RFTM-Lugol's iodine processed samples could be quantified, with DNA con-

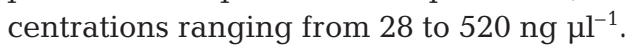

\section{PCR results}

Using the Perkinsus genus-specific primers (PerkITS), Perkinsus DNA was amplified by PCR in each of the tissue samples testing positive by RFTM assays ( $\mathrm{n}=$ 58, Table 1). Interestingly, PCR amplifications were also observed in all tissue samples that were negative by RFTM assays (9/9).

When the same DNAs were tested using the Perkinsus marinus-specific PCR assay, amplifications were observed for a majority of samples (55/58) testing positive by RFTM assays (Table 1). As observed with PerkITS primers, $P$. marinus was also detected by PCR in samples found negative by RFTM assays (8/9 samples). Finally, with the $P$. chesapeaki-specific PCR assay, $P$. chesapeaki was not detected in any of these samples.

\section{DISCUSSION}

We have demonstrated that DNA can be extracted and PCR-amplified successfully from a majority of RFTM-Lugol's iodine-processed samples. To our knowledge, this study was the first to investigate whether molecular tools could be applied to shellfish tissues processed by RFTM and stained with Lugol's iodine. Although a previous study showed that DNA could be extracted and amplified by PCR from tissues incubated in RFTM, it did not investigate the potential use of molecular tools on shellfish tissues exposed to iodine solution (Novoa et al. 2002). The potential bind- 
ing of iodine to DNA, thereby making DNA inaccessible to amplification, has been postulated as a reason for the absence of PCR amplification observed for some Lugol's iodine-fixed samples (Marin et al. 2001, Godhe et al. 2002). However, other studies have shown that PCR amplification could be obtained after exposure of dinoflagellates or nematode eggs to Lugol's iodine (Tengs et al. 2001, Galluzzi et al. 2004, Harmon et al. 2007). Discrepancies between these studies may be due to the type of sample analyzed or the duration of the fixation in Lugol's iodine. In our case, the exposure to Lugol's iodine was less than $3 \mathrm{~h}$, which may have prevented excessive DNA damage.

Using the same tissue sample, it was possible to first detect a Perkinsus spp. infection using RFTM-Lugol's iodine, and then to identify the Perkinsus species responsible for this infection by PCR. The detection by PCR of $P$. marinus but not of the sympatric $P$. chesapeaki suggests that the Crassostrea virginica analyzed in this study were only infected by $P$. marinus, a $P$. marinus host specificity that was previously postulated by La Peyre et al. (2006). Using the PerkITS assay, amplifications were observed for all of the samples found positive by RFTM assays as well as for the samples testing negative by RFTM assays. Using the PmarITS assay, amplifications were observed for all the samples testing positive by RFTM assays except for a few rare or light infections. Using this PCR assay, P. marinus DNA was also detected in a majority of samples testing negative by RFTM assays. This could be due to a higher sensitivity of these PCR assays, and of the PerkITS assay in particular, compared to RFTM assays, as demonstrated for other PCR assays for P. marinus (Marsh et al. 1995, Robledo et al. 1998, Yarnall et al. 2000, Gauthier et al. 2006). As previously suggested (Audemard et al. 2004), the PerkITS assay may be slightly more sensitive than the PmarITS assay, since the overall number of positive PCR results was higher with PerkITS than with PmarITS. Nevertheless, most of the infections detected by RFTM assays were associated with PCR amplification using PmarITS primers.

Being able to apply PCR to DNAs from RFTMLugol's iodine-processed samples could be particularly useful in the context of a Perkinsus sp. survey in a new host species or outside the known geographical range of a particular Perkinsus species. In such studies (e.g. Park \& Choi 2001, Leethochavalit et al. 2004), RFTM assays were used to detect Perkinsus spp. infections due to low cost, simplicity of use, and sensitivity. The identification of the species responsible for the detected infections, however, necessitated further sampling or further studies where tissue samples were specifically collected for molecular analysis (Park et al. 2005). Here, we demonstrated that when such surveys are conducted, tissues found positive by RFTM-Lugol's iodine assays can be preserved in $95 \%$ ethanol for further molecular analysis, providing a gain of time and a reduction of the cost since only the positive samples for RFTM assay need to be processed using the costly molecular tools. The DNA extracted from these tissues can then be analyzed by PCR and sequenced if necessary. Preservation in $95 \%$ ethanol in particular will allow laboratories without molecular biological capabilities to store post-RFTM assays Perkinsus sp.-positive tissues stably and indefinitely, until they can be transported to a suitable laboratory for further characterization.

Acknowledgements. J. Wesson and M. Southworth collected the oysters used in this study. R. Crockett and S. Denny processed the oysters and performed the RFTM analyses. This is VIMS contribution no. 2948.

\section{LITERATURE CITED}

Audemard C, Reece KS, Burreson EM (2004) Real-time PCR for detection and quantification of the protistan parasite Perkinsus marinus in environmental waters. Appl Environ Microbiol 70:6611-6618

Blackbourn J, Bower SM, Meyer GR (1998) Perkinsus qugwadi sp. nov. (incertae sedis), a pathogenic protozoan parasite of Japanese scallops, Patinopecten yessoensis, cultured in British Columbia, Canada. Can J Zool 76: 942-953

Burreson EM, Reece KS, Dungan CF (2005) Molecular, morphological, and experimental evidence support synonymy of Perkinsus chesapeaki and Perkinsus andrewsi. J Eukaryot Microbiol 52:258-270

> Casas SM, Grau A, Reece KS, Apakupakul K, Azevedo C, Villalba A (2004) Perkinsus mediterraneus n. sp., a protistan parasite of the European flat oyster Ostrea edulis from the Balearic Islands, Mediterranean Sea. Dis Aquat Org 58: 231-244

> Dungan CF, Reece KS (2006) In vitro propagation of two Perkinsus spp. parasites from Japanese Manila clams Venerupis philippinarum and description of Perkinsus honshuensis n. sp. J Eukaryot Microbiol 53:316-326

Elston RA, Dungan CF, Meyers TR, Reece KS (2003) Perkinsus sp. infection risk for manila clams, Venerupis philippinarum, (A. Adams and Reeve, 1850) on the Pacific Coast of North and Central America. J Shellfish Res 22:667-674

Galluzzi L, Penna A, Bertozzini E, Vila M, Garces E, Magnani M (2004) Development of a real-time PCR assay for rapid detection and quantification of Alexandrium minutum (a dinoflagellate). Appl Environ Microbiol 70:1199-1206

> Gauthier JD, Miller CR, Wilbur AE (2006) Taqman MGB realtime PCR approach to quantification of Perkinsus marinus and Perkinsus spp. in oysters. J Shellfish Res 25:619-624

Godhe A, Anderson DM, Rehnstam-Holm AS (2002) PCR amplification of microalgal DNA for sequencing and species identification: studies on fixatives and algal growth stages. Harmful Algae 1:375-382

Goggin CL (1994) Variation in the two internal transcribed spacers and 5.8S ribosomal RNA from five isolates of the marine parasite Perkinsus (Protista, Apicomplexa). Mol Biochem Parasitol 65:179-182

> Harmon AF, Williams ZB, Holler LD, Hildreth MB (2007) Comparison of three different preservatives for morpho- 
logical and real-time PCR analyses of Haemonchus contortus eggs. Vet Parasitol 145:361-365

La Peyre M, Casas S, La Peyre J (2006) Salinity effects on viability, metabolic activity and proliferation of three Perkinsus species. Dis Aquat Org 71:59-74

Leethochavalit S, Chalermwat K, Upatham ES, Choi KS, Sawangwong P, Kruatrachue M (2004) Occurrence of Perkinsus sp. in undulated surf clams Paphia undulata from the Gulf of Thailand. Dis Aquat Org 60:165-171

Lester RJG, Davis GHG (1981) A new Perkinsus species (Apicomplexa, Perkinsea) from the abalone Haliotis ruber. J Invertebr Pathol 37:181-187

Mackin JG, Owen HM, Collier A (1950) Preliminary note on the occurrence of a new protistan parasite, Dermocystidium marinum n. sp. in Crassostrea virginica (Gmelin). Science 111:328-329

Marin I, Aguilera A, Reguera B, Abad JP (2001) Preparation of DNA suitable for PCR amplification from fresh or fixed single dinoflagellate cells. Biotechniques 30:88-93

Marsh AG, Gauthier JD, Vasta GR (1995) A semiquantitative PCR assay for assessing Perkinsus marinus infections in the eastern oyster, Crassostrea virginica. J Parasitol 81: 577-583

McLaughlin SM, Faisal M (1999) A comparison of diagnostic assays for detection of Perkinsus spp. in the softshell clam Mya arenaria. Aquaculture 172:197-204

Moss JA, Xiao J, Dungan CF, Reece KS (2008) Description of Perkinsus beihaiensis n. sp., a new Perkinsus sp. parasite of oysters of Southern China. J Eukaryot Microbiol 55:117-130

Novoa B, Ordas MC, Figueras A (2002) Hypnospores detected by RFTM in clam (Ruditapes decussatus) tissues belong to two different protozoan organisms, Perkinsus atlanticus and a Perkinsus-like organism. Aquaculture 209:11-18

Editorial responsibility: Mike Hine,

Fouras, France
Park KI, Choi KS (2001) Spatial distribution and infection intensity of the protozoan parasite Perkinsus sp. in the manila clam Ruditapes philippinarum in Korea. Aquaculture 20:9-22

- Park KI, Park JK, Lee J, Choi KS (2005) Use of molecular markers for species identification of Korean Perkinsus sp. isolates from Manila clams Ruditapes philippinarum. Dis Aquat Org 66:255-263

$>$ Ray SM (1952) A culture technique for the diagnosis of infections with Dermocystidium marinum, Mackin, Owen and Collier, in oysters. Science 116:360-361

Ray SM (1954) Biological studies of Dermocystidium marinum, a fungus parasite of oysters. Rice Institute Pamphlet, Special Issue 41:1-114

Ray SM (1966) A review of the culture method for detecting Dermocystidium marinum, with suggested modifications and precautions. Proc Natl Shellfish Assoc 54:55-69

Robledo JAF, Gauthier JD, Coss CA, Wright AC, Vasta GR (1998) Species-specificity and sensitivity of a PCR-based assay for Perkinsus marinus in the eastern oyster, Crassostrea virginica: a comparison with the fluid thioglycolatte assay. J Parasitol 84:1237-1244

> Tengs T, Bowers HA, Ziman AP, Stoecker DK, Oldach DW (2001) Genetic polymorphism in Gymnodinium galatheanum chloroplast DNA sequences and development of a molecular detection assay. Mol Ecol 10:515-523

> Villalba A, Reece KS, Ordas CM, Casas SM, Figueras A (2004) Perkinsiosis in molluscs: a review. Aquat Living Resour 17: 411-432

> Yarnall HA, Reece KS, Stokes NA, Burreson EM (2000) A quantitative competitive polymerase chain reaction assay for the oyster pathogen Perkinsus marinus. J Parasitol 86: $827-837$

Submitted: February 1, 2008; Accepted: June 2, 2008 Proofs received from author(s): July 14, 2008 